\title{
Discovering Patterns in Regulatory History: Continuity, Change, and Regulatory Regimes
}

From contesting the power of large corporations to nurturing a stable industrial economy, regulatory policies have been created in pursuit of a wide variety of goals. Likewise, regulatory institutions have been designed to address a host of administrative demands, to incorporate organized interests into the policy process, and to compensate for specific problems of implementation. One can analyze each expansion of regulatory authority as an independent event. However, one can bring order to the history of regulation by identifying particular regimes that have emerged during critical periods in U.S. history. When used in international relations, a regime is commonly defined as "a set of principles, norms, rules, and procedures around which actors' expectations converge." In this context, regimes are important because they "constrain and regularize the behavior of participants, affect which issues among protagonists move on and off agendas, determine which activities are legitimized or condemned, and influence whether, when, and how conflicts are resolved." While retaining the emphasis on a value-based governance structure, we can define a regulatory regime as a linked set of policies and institutions that condition the relationship between societal interests, the state, and economic actors in multiple sectors of the economy. A regime framework focuses attention on points of continuity in policy and institutional change. It facilitates the discovery of patterns in regulatory policies and institutions and provides a useful explanatory and organizational tool.

In this article, I use a regulatory regime framework to examine policy change and institutional evolution in four periods; the Progressive Era, the New Deal, the early 1970s, and the contemporary period. Because of space limitations and the breadth of the topic, the goal is simply to explore the origins and identify the key elements of the regimes created in these periods. ${ }^{2}$

JOURNAL OF POLICY HISTORY, Vol. 6, No. 2, 1994.

Copyright $(\mathcal{O} 1994$ The Pennsylvania State University Press, University Park, PA. 
Reflecting the complex administrative and technical features of many regulatory policies, regulatory studies usually adopt a policy-specific focus. Despite the considerable merits of policy-specific studies, this approach is too narrow to place regulatory initiatives within the appropriate historical and social context. Of course, addressing multiple policies carries the obvious cost of sacrificing analytical depth to achieve greater coverage. However, it is an important first step to introducing greater order into the study of regulation.

\section{Continuity and Change in Regulatory History}

Economic structural change undermines established economic routines and places pressure on the existing distribution of wealth and economic power. Economic and social groups react to structural transformation by placing demands on public officials to extend public authority to new areas of economic activity. However, demands are disparate and unfocused, reflecting the diversity of the interests involved. While it is often possible to identify regional and sectoral differences in the demands for regulatory policy and thus divide the political spectrum into competing political-economic blocs, the differences are often too numerous to facilitate easy categorization. Prevailing political-economic doctrines go far in imposing order on this chaos by providing overarching interpretations of a complex reality and linking a host of separate economic and social changes to common factors. Moreover, they suggest policy responses that are both feasible and legitimate. While ideas are critical, we must take care not to fall into intellectual determinism. Ideas rarely play an independent role. Rather, political entrepreneurs creatively link them to group demands and use them as tools of coalition building. Ideas affect policy in a second context. When group demands are diverse and conflictive due to regional cleavages or other factors, it may be necessary to sacrifice legislative precision and define policy goals abstractly. The resulting delegation of authority displaces conflicts to the administrative arena. Prevailing political-economic doctrines are more influential within the confines of the bureaucracy where they can serve as the core of an elite consensus. While the delegation of authority resolves the immediate problem of incompatible demands, it simultaneously places a premium on the expertise of administrators, the structure of regulatory agencies, and the allocation of resources. ${ }^{3}$

Agencies evolve in response to the demands of implementation; the way they evolve limits the range of feasible policies. A host of factors shapes administrative capacities, including experience with a given set of policies, established bureaucratic routines, the availability of policy exper- 
tise, and well-entrenched relationships with organized economic interests. ${ }^{4}$ Because administrative capacities impose distinct limitations on policymakers, it is often necessary to combine new policies with experiments in institutional design. In each regulatory regime, policymakers coupled regulatory initiatives with administrative innovations chosen in response to past implementation problems, the demands of new policies, and dominant administrative reform doctrines.

One can recognize the emergence of a new regime when regulatory policy initiatives and institutional innovations introduced across a number of areas reveal similar goals, patterns of state-economy relations, and administrative models. The commonality across regulatory arenas results from the influence of prevailing political-economic ideas and coalitions, and the common reference to the economic-structural changes in question. Rather than concentrating solely on the stated objectives of specific regulatory policies addressing agriculture, labor relations, and corporate finance, for example, a regime framework forces one to determine what the initiatives of a given period were designed to accomplish, when taken together. How did the new policies change dominant patterns of state-economy relations? How did they alter the role of interests and competing institutions in the regulatory process?

One can identify four unique regulatory regimes. The Progressive Era's market regime was constructed around policies designed to revitalize markets or produce marketlike results through administrative means. The New Deal's associational regime, in contrast, included policies that promoted industrial stability and institutions that provided a distinctive role for interests in a system of government-supervised industrial self-regulation. The 1960 s and 1970s brought a new societal regime based on policies that addressed the social consequences of industrial production and required administrators to place an unprecedented reliance on social scientific and scientific expertise in defining standards. Finally, the efficiency regime of the 1970s and 1980s was based on a heightened reliance on decentralized markets and, ironically, centralized review in the Executive Office of the President. Key features of these four regimes are presented in Table 1.

A regime framework highlights the continuity-common patterns of state-economy relations, overarching policy goals, and administrative models-that characterizes the policy initiatives in a given period. It also focuses attention on regulatory change. However, the emergence of a new regulatory regime does not result in the elimination of an earlier regime. The existence of overlapping regulatory regimes is a product of the fragmentation of American institutions. The capacity of an agency to resist change is a product of its relationships with key interests and congressional committees, existing jurisdictional boundaries, and the specialized 
Table 1. Characteristics of regulatory regimes

\begin{tabular}{lll}
\hline Regime & Market Regime & Associational Regime \\
\hline $\begin{array}{l}\text { Primary } \\
\text { Goal }\end{array}$ & $\begin{array}{l}\text { Promotion of market gover- } \\
\text { nance; creation of marketlike } \\
\text { results through administra- } \\
\text { tive means }\end{array}$ & $\begin{array}{l}\text { Promotion of industrial stabil- } \\
\text { ity and redistribution of na- } \\
\text { tional income toward regu- } \\
\text { lated }\end{array}$
\end{tabular}

Political Emergence of large-scale corEconomic porate economy and national Context markets during period 1880 1920

Institutional Broad reliance on indepenInnovation dent commissions and boards
Policy Initiatives

Role of Expertise

Integration of Interests
Antitrust and regulation of railroads, commercial banking, foods and drugs

Progressive efforts to promote and foster neutral competence; some reliance on specialized expertise in commissions

Interests integrated at legislative level; little regulation of interaction at administrative level
Collapse of industrial and agricultural economies during the Great Depression

Interest associations as quasipublic entities defining and implementing policies

National Industrial Recovery Act and new regulatory systems in agriculture, commercial and industrial finance, and labor relations

Broad reliance on specialists within key agencies; efforts to tap private-sector expertise through close relations with the regulated

Interests integrated through the creation of quasicorporatist arrangements and government supervised self regulation

Efficiency Regime

\begin{tabular}{ll} 
Regime & Societal Regime \\
\hline Primary & $\begin{array}{l}\text { Prevention of hazards to } \\
\text { Goalth and environment that } \\
\text { Occur in advanced capitalist } \\
\text { production }\end{array}$
\end{tabular}

PoliticalEconomic Postwar growth promoting Context
Elimination of policies that interfere with market mechanisms or impose large compliance costs

Economic stagflation and growing foreign competition in the 1970s and 1980s the emergence of postmaterial values and quality of life concerns 
Table 1. cont.

\begin{tabular}{|c|c|c|}
\hline Regime & Market Regime & Associational Regime \\
\hline $\begin{array}{l}\text { Institutional } \\
\text { Innovation }\end{array}$ & $\begin{array}{l}\text { Limits on agency discretion } \\
\text { imposed through action- } \\
\text { forcing mandates and imple- } \\
\text { mentation timetables }\end{array}$ & $\begin{array}{l}\text { Centralization of regulatory } \\
\text { authority and formal review } \\
\text { in the Office of Management } \\
\text { and Budget, White House re- } \\
\text { view offices, and agency eval- } \\
\text { uation offices }\end{array}$ \\
\hline $\begin{array}{l}\text { Policy } \\
\text { Initiatives }\end{array}$ & $\begin{array}{l}\text { New social regulations focus- } \\
\text { ing on environmental qual- } \\
\text { ity, worker safety and health, } \\
\text { and consumer protection }\end{array}$ & $\begin{array}{l}\text { Executive orders requiring } \\
\text { formal economic analysis of } \\
\text { regulation; deregulatory legis } \\
\text { lation addressing surface } \\
\text { transportation, airlines, and } \\
\text { finance }\end{array}$ \\
\hline $\begin{array}{l}\text { Role of } \\
\text { Expertise }\end{array}$ & $\begin{array}{l}\text { Expansive reliance on scien- } \\
\text { tific and social-scientific ex- } \\
\text { pertise as a result of the } \\
\text { complexity of new social } \\
\text { regulations }\end{array}$ & $\begin{array}{l}\text { Formal application of eco- } \\
\text { nomic evaluation methodolo- } \\
\text { gies (e.g., cost-benefit and } \\
\text { cost-effectiveness analysis) } \\
\text { and risk assessment }\end{array}$ \\
\hline $\begin{array}{l}\text { Integration } \\
\text { of Interests }\end{array}$ & $\begin{array}{l}\text { Interests integrated through } \\
\text { extended rulemaking process, } \\
\text { intervener funding, and ex- } \\
\text { panded access to courts }\end{array}$ & $\begin{array}{l}\text { No innovations in formal in- } \\
\text { terest integration; informal } \\
\text { access to White House re- } \\
\text { view offices }\end{array}$ \\
\hline
\end{tabular}

discourse that surrounds most policies. As policies become embedded in institutions, they shape political alliances and investment decisions. Agencies nurture external constituencies and become resistant to change.

\section{Regulation and the Decline of the Market Economy}

The market regime finds its roots in the spectacular structural transformation of the last third of the nineteenth century. From the late 1860 s to the 1890 s, capital stock per worker increased by 80 percent. The new corporate economy, with its distinctive technological and organizational features (e.g., standardized large-batch and continuous-batch production technologies, hierarchical multidivisional organization) allowed for greater efficiency and economies of scale. While the manufacturing workforce remained relatively stable as a percentage of the population, manufacturing 
output increased from 33 percent of all commodities in 1869 to 53 percent twenty-five years later. However, the new corporate economy suffered persistent problems of overproduction. Hoping to coordinate expansion and introduce greater stability, corporations increasingly turned toward the trust. While some 300 "trusts" (i.e., trusts and holding companies) existed by 1904 , the legal challenge of the Sherman Antitrust Act stimulated a wave of corporate consolidations as businesses attempted to avoid the legal restraints on "loose" combinations. Between 1897 and 1904, 4,227 firms merged to create 257 combinations, dramatically increasing the concentration of the economy. Following this period of intensive industrial consolidation, one percent of the companies controlled the production of some 45 percent of manufactured goods. ${ }^{5}$ Capital-intensive corporations in the dynamic core industries commonly attempted to manage expansion through the formation of trusts, holding companies, and consolidation. Peripheral firms in decentralized industries created trade associations to formulate policies and common strategies to promote stability. Once organized by national business associations like the National Association of Manufacturers and the National Board of Trade, these firms became active proponents of regulatory policies to offset the challenges of the industrial core. ${ }^{6}$

The compulsion to organize, clearly displayed in the activities of corporate managers, found another expression, quite naturally, in labor and agriculture. During the decades following the Civil War, workers joined several labor organizations, including the National Labor Union, a host of industry-specific unions, and the Knights of Labor, an organization that could claim to represent more than seven-hundred-thousand craft and industrial workers by 1886 . The Knights fell into rapid decline following the reactions to Haymarket Square and the concerted efforts of large labor-intensive firms to repel the demands of strikers. However, the American Federation of Labor filled the gap by providing national representation to union locals of skilled and semiskilled craft workers. The membership of the AFL grew rapidly, from 250,000 in 1897 to 1,562,000 in 1910, and doubled again in size by the eve of World War I. ${ }^{7}$

Organization also held great attraction in agriculture. The Granger movement promoted local cooperative organizations to unite farmers for purchasing and marketing purposes. It simultaneously provided a basis for political mobilization. Farm groups, often working in concert with small merchants, focused on the symbols of the new organized economy: the railroads and trusts. The Populists continued the activities of the Grangers in the 1890 s, calling for nationalization of the railroads and banks and the increase of farm commodity prices through the coinage of silver. They also entered partisan politics both as a third party and through close alliances with the 
Democratic Party. Following the Republican ascendancy in the realignment of 1896, the Populists' influence quickly declined. ${ }^{8}$

The changes of the late nineteenth century shaped the organization and mobilization of new interests and gave rise to new demands. While many groups encouraged reform, their specific goals differed widely. Most saw the decline of the local market system and the growth of the new corporate economy as threats to the existing distribution of power and patterns of economic activity. While the demands for reform stemmed from a common cause, the diversity of interests undermined the coherence of the reform agenda, providing ample opportunities for elites to introduce their own plans. Progressivism provided a set of organizing principles that promoted coalition-building and gave direction to the uncoordinated demands for change.

Group demands are often vague, sectarian, and locally oriented. To build a sufficient legislative coalition, policymakers must integrate group demands and link them to concrete policy proposals. The market regime emerged in response to the transformation of the late nineteenth century. However, the core policies and institutional innovations took shape once they were integrated with the Progressive reform agenda. The Progressives inherited much of their program from the nineteenth-century reform movements addressing the problems of economic change, urban poverty, and political corruption. This reform legacy-particularly that of the Social Gospel movement-provided the Progressives an agenda with distinct political and moral dimensions. ${ }^{9}$

The chief reforms of the period were achievable, in large part, because of change in the political environment and the distinctive intellectual features of Progressivism. The highly competitive partisan politics of the late-nineteenth century thwarted reforms that might stress fragile party coalitions. The realignment of 1896 that resulted in Republican hegemony opened new legislative opportunities. However, one must also focus on the distinctive link Progressivism forged between reform initiatives and scientific knowledge. ${ }^{10}$ At the core of Progressivism was the belief that officials could design policies and institutions rationally to restrain or direct social and economic change. The confidence that scientific and social scientific knowledge offered a key to the improvement of the human condition was derivative of a period that witnessed a great expansion of the university system, a sevenfold increase in the professoriate, and the organization of the formal disciplines. ${ }^{11}$ As part of this process, many reflected on the role of intellectuals and the organized disciplines in guiding social change. Key founders and early members of the American Economic Association, for example, had close ties to the Social Gospel 
movement and envisioned a union of social science and reform. As the founding platform of the American Economic Association proclaimed: "We regard the state as an educational and ethical agency whose positive aid is an indispensable condition of human progress." One could not address the economic conflicts "without the united efforts of church, state, and science."12

The strong democratic aspects of Progressivism-clearly expressed in the electoral and party reforms of the period and the sympathetic posture toward populism-stood in a tense relationship with the faith in science and elite social engineering. While some Progressives valued reform as a means of protecting individual autonomy and opportunity, others endorsed the creation of institutions that could transform individuals and society. These populist and paternalist strands found a clear expression in the debates surrounding regulation. Although all Progressives acknowledged the fruits of corporate efficiency, many saw the concentration of economic power as a threat to political and economic liberties. Louis Brandeis remarked: "The displacement of the small independent business man by the huge corporation with its myriad of employees, its absentee ownership and its financier control presents a grave danger to our democracy." This "process of capitalizing free Americans" is neither inevitable nor "even in accord with the natural law of business. It is largely the result of unwise, man-made, privilege-creating law, which has stimulated existing tendencies to inequality instead of discouraging them." 13 The laws that facilitated corporate expansion could be recast to promote decentralized markets. Many Progressives, including Louis Brandeis, Robert LaFollette, and Woodrow Wilson, believed that one could use antitrust to disperse corporate power and eliminate the practices that victimized consumers, workers, and small businesses.

The northeastern wing of the Republican Party offered an opposing vision of the role of the state in the economy. Following Herbert Croly, Theodore Roosevelt envisioned a state facilitating and directing economic change through close relationships with corporations and economic interest groups. If the large corporations of the industrial core were the natural and beneficial ends of economic and organizational evolution, one could have little empathy for "the foolish radicals who desire to break up all big business, with the impossible ideal of returning to midnineteenth century industrial conditions." As Roosevelt noted: "Combinations in industry are the result of an imperative economic law which cannot be repealed by political legislation. . . . The way out lies, not in attempting to prevent such combinations, but in completely controlling them in the interest of the public welfare." 14 As part of his New National- 
ism, he called for an agency modeled on the Bureau of Corporations to collect data on corporate activity, supervise capitalization, and regulate labor relations. The agency would enforce the Sherman Act cautiously, on the basis of conduct rather than size. To a great extent, elite negotiation and cooperative planning would displace the chaotic conditions of the market.

During the 1912 campaign, Wilson unveiled his New Freedom as a rejoinder to the corporation of Roosevelt's New Nationalism. A number of semantic disputes veiled the common recognition of corporate efficiency. The key disagreement centered on the role of the state in the economy. Wilson viewed Roosevelt's plan as one in which the large corporations would be "recognized as a permanent part of our economic order" and made "the ministers, the instruments, through which the life of this country shall be justly and happily developed on its industrial side." Under such an arrangement, he charged, the large corporations would have to "capture the government, in order not to be restrained too much by it." 15 Thereafter, citizens would be dependent on the benevolence of the state and the large corporations. On these grounds, Wilson called for an extension of the Sherman Act to address the practices that promoted the formation of monopoly power. Regulation would become a form of law enforcement aimed at maintaining markets. In the end, the Wilsonian vision proved more representative of regulation under the market regime.

\section{Delegation and Institutional Failure}

The period's contributions to the regulatory state are substantial. During the period, Congress passed the Interstate Commerce Act (1887), creating the Interstate Commerce Commission; the Sherman Antitrust Act (1890), establishing the foundation of antitrust; the Hepburn Act (1906), creating explicit ratemaking powers for the ICC; the Meat Inspection Act and the Pure Food and Drug Acts (1906), initiating the regulation of meat and foodstuffs, the Federal Reserve Act (1913), creating a Federal Reserve Board and expanding national regulation of finance; and the Federal Trade Commission and Clayton Acts (1914), strengthening the provisions and enforcement of antitrust.

A brief examination of the Interstate Commerce Commission (ICC) and the Federal Trade Commission (FTC) reveals several factors that limited the success of early initiatives. First, Congress defined policy goals and prohibitions abstractly, creating uncertainty about the aims of the legislation and the limits of agency discretion. In the Interstate Com- 
merce Act, for example, Congress employed nebulous terms like "unjust and unreasonable charges," "unjust discrimination," and "undue and unreasonable prejudice or disadvantage," while depriving the newly created commission of guidance in determining how to apply such provisions. If regulatory complexity and the consequent uncertainty forced a degree of legislative imprecision, it was also politically expedient. Agrarian radicals attempted to restrain the emerging corporate order, large railroads hoped to escape the radicalism and confusion of state-level regulations, and a variety of shippers attempted to gain lower rates and deter discriminatory practices. Unable to resolve the irreconcilable demands, Congress chose to displace the rivalry to the administrative and judicial arenas.

With the broad statutory mandates and consequent delegation, regulatory success was contingent on the resources devoted to administration. However, Congress routinely failed to back its ambitious mandates with sufficient resources. In the extreme case of the Sherman Act, Congress neglected to appropriate any funds at all. ${ }^{16}$ Resource scarcity and the nation's limited regulatory experience enfeebled attempts to create staffs with the necessary expertise. One must place the early regulatory legislation in historical perspective. At the turn of the century, the American government was without a regulatory tradition to inform the implementation of the new statutes. To be certain, Progressive doctrines of public administration popularized by Frank Goodnow and Woodrow Wilson, among others, suggested the importance of neutral administration, expertise, and hierarchical control of the bureaucracy. Indeed, their influence was magnified by their introduction during this formative period in the development of the regulatory state. However, a dearth of resources and experience placed severe limitations on the administrative capacities of regulatory agencies. When compared with the corporations they regulated, agencies like the ICC, the FTC, and the Justice Department lacked the resources and the expertise to constitute a serious challenge. ${ }^{17}$

A third factor shaping performance was the resistance of other institutions to any large extension of regulatory authority. The courts placed distinct limits on agency authority by employing conservative interpretations of the interstate commerce clause and the powers that could derive from vague legislative mandates. For example, in the 1897 Maximum Rate Case, the Supreme Court decided that while the ICC could determine whether a rate was unreasonable, it could not determine what rates would be reasonable. The latter was a legislative power that had not, in the Court's opinion, been delegated. Following a series of negative decisions, the ICC's annual report stated: "By virtue of judicial decisions, [the ICC] has ceased to be a body for the regulation of interstate carriers. It is proper 
that Congress should understand this. The people should no longer look to this Commission for a protection which it is powerless to extend." 18

When agencies faithfully executed their mandates, the resulting political mobilization could invoke strong congressional opposition. ${ }^{19}$ Take, for example, the FTC's meatpacking investigation, conducted in 1918 at the request of President Wilson. After a lengthy investigation, the FTC recommended that the government take control of and administer the rail cars, stockyards, warehouses, and cold-storage facilities and operate them as a "government monopoly" to create "open, competitive markets, with uniform scale of charges for all services performed" and "afford an outlet for all manufacturers . . . on equal terms." ${ }^{20}$ The FTC's report and recommendations mobilized the opposition of the meatpackers and a host of unrelated industries. Following hearings where Congress attacked the FTC for producing a biased report drafted to support radical proposals, it forced the agency to absorb large budget cuts, staff reductions, and the abandonment of several investigations. Ultimately, the Packers and Stockyards Act of 1921 eliminated FTC jurisdiction over the meatpacking industry. ${ }^{21}$

The ICC and the FTC, two of the most prominent regulatory agencies of the market regime, encountered similar destinies. The imprecision of legislative mandates and the resulting delegation of authority created great uncertainly. The electoral vulnerability of Congress, the central role of the courts in regulation, and the adversarial relationship between regulators and the regulated were all decisive. The agencies were restrained when their rulings provoked a political response from the regulated or violated prevailing judicial norms of market governance and a limited state role in regulating commerce. These features of regulation would change in subsequent decades with the emergence of the associational regime.

\section{Regulatory Responses to Economic Collapse}

Although the New Deal witnessed the formation of the associational regime, the key features of the regime-a system of government-supervised self-regulation and the goal of promoting stability-found their origins some fifteen years earlier. World War I redefined the role of the state in the economy, legitimizing an expansion of regulatory authority. At the same time, economic associations grew in number and sire. Driven by the close relationships with government officials during the war and the probusiness posture of postwar administrations, they sought 
to play a more central role in the definition or regulatory policy. The new goal of promoting stability (i.e., limiting competition and guaranteeing profitability) and the integration of associations into the regulatory process diminished the adversarial qualities of regulation and the role of Congress and the courts.

The War Industries Board (WIB) was the central agency responsible for economic mobilization. President Wilson described its duties broadly, to include: "(1) The creation of new facilities and the disclosing, if necessary, the opening up of new or additional sources of supply; (2) The conversion of existing facilities, where necessary, to new uses; (3) The studious conservation of resources and facilities by scientific, commercial and industrial economies; (4) Advise to the several purchasing agencies of the Government with regard to the prices to be paid; (5) The determination, wherever necessary, of priorities of production and of delivery and of the proportions of any given article to be made immediately accessible to the several purchasing agencies when the supply of that article is insufficient, either temporarily or permanently; [and] (6) The making of purchases for the Allies." 22

Wilson gave Bernard Baruch, chairman of the WIB, final authority in all areas except price fixing. Despite the great centralization of authority, two factors hampered the WIB's efforts. First, Congress did not give the WIB the formal sanctions necessary to implement its mandate, giving rise to persistent problems of coordination. The WIB had the power to establish priorities and to commandeer plants, but these were very blunt tools. In the end, Baruch was most successful when relying on negotiations with representatives of industry and the armed services. Second, despite the complexity inherent in mobilizing one-quarter of the nation's economic output, the WIB lacked the necessary staff and expertise. The WIB compensated for this deficit by creating fifty-seven commodity sections staffed by industry and the services. The sections worked closely with war service committees organized by the U.S. Chamber of Commerce and trade associations to examine future needs, existing production levels and capacities, and prices. These trade associations, in turn, provided much of the support and staffing for the commodity sections. ${ }^{23}$

The WIB conveyed quasi-official status on the trade associations and the war service committees. This created distinct but predictable problems. As Robert Cuff explains: "Technical skill was concentrated along the outer edges of the WIB, within the commodity sections. This had important consequences for the distribution of authority within the organization, for it meant that much of the daily decisionmaking affecting industry took place here through close consultation between industrial 
representatives and the various section heads. Decisions occurred, in other words, where the territory of the board and of industry overlapped, beyond the reach of central officials." The opportunities for abuse were obvious: "If the commodity chief became a lobbyist for his industry . . . there was little the board could do about it." 24 In the end, the brevity of U.S. involvement and rapid demobilization limited the impact of these problems.

Despite the mixed record, the wartime experience introduced a generation to the potential benefits of planning. As Ellis Hawley explains, many viewed mobilization "not only as a requirement for survival but as a stepping stone to the social order that a progressive era had envisioned but failed to achieve. A system of war management, they came to believe, could be adapted to the peacetime management of social programs." 25 Many government and corporate officials entered the 1920s after having played some role in the mobilization effort. The war presented new models of state-economy relations and stimulated the creation of new economic associations that continued to operate after the war. New patterns of state-corporate relations, a new universe of industrial organizations, and elites experienced in working with the federal government became some of the chief legacies of the war.

Herbert Hoover, among others, drew on his wartime experiences to promote a distinctive model of the state-economy relations. He called for "a plan of individualism and associational activities that will preserve the initiative, the inventiveness, the individuality, the character of man and yet will enable us to synchronize socially and economically this gigantic machine that we have built out of applied science." 26 The government could employ a network of trade associations such as those central to the mobilization process to coordinate and rationalize production, eliminate excessive competition, and promote standardization. By coordinating associational activities, the state could promote a form of stateless planning. Scores of corporate leaders, bureaucrats, and intellectuals shared this associationalist vision. As Secretary of Commerce, Hoover expanded the department and entered entirely new areas of activity. By 1924, Hoover was actively promoting associationalism through close contacts with the Interior Department, the Labor Department, the Agriculture Department, the Justice Department's Antitrust Division, and the Federal Trade Commission. For example, under the direction of FTC Chairman William Humphrey, the FTC worked with the Commerce Department to promote trade practice conferences at which corporations and trade associations developed codes of conduct and standards. In 1929 alone, the FTC held some fifty trade practice conferences. The goals of the activities 
at the FTC and other agencies were to promote "progressive organization and practice" and "to reinforce private ordering mechanisms with governmental power or approval."27

Hoover's reputation, his confidence in the progressive impulses of business, and the record of economic growth amplified his business support as president. Hoover responded to the 1929 economic collapse by convening a series of conferences with business, labor, and farm associations to win voluntary agreements to limit future deflation, maintain employment levels, and promote wage stability. ${ }^{28}$ Business support quickly disintegrated despite Hoover's procorporate posture and the constant consultation. Republican tariff policy and commitment to the gold standard created divisions within business and finance and raised the opposition of many of the largest corporations and banks that hoped to maintain and expand access to international markets. ${ }^{29}$ Although Hoover offered the elements of an associationalist recovery plan, it was cautious and pallid when compared with the alternatives presented by industrialists, academics, and policymakers. Bernard Baruch and William McAdoo called for the creation of a Peace Industries Board. Others, including Stuart Chase, Charles Beard, George Soule, and the National Civic Federation presented proposals for planning agencies of one type or another. In 1932, more than onehundred business representative asked Hoover to create a National Economic Truce Board, a planning agency modeled on the WIB. The most influential plan was that devised by General Electric President and WIB verteran Gerald Swope, which would have used trade associations to collect information and promote coordination, allowing corporations to manage production under an antitrust exemption. A new agency, in turn, would play a supervisory role. Although the Swope plan received the broad support of the Chamber of Commerce and former WIB officials, Hoover rejected it as "the most gigantic proposal of monopoly ever made in American history." 30

Hoover's intransigence, the rapid economic plunge, and the dissatisfaction over tariff and monetary policies were sufficient to force the collapse of the already frayed Republican coalition. By the fall of 1932, the Chamber of Commerce and officials drawn from some of the largest corporations in the nation switched allegiances to support Roosevelt. Many combined support for Roosevelt with the belief that recovery would necessitate close government-industry cooperation. ${ }^{31} \mathrm{~W}$ ith the experience of the war, the associationalism and New Era economics of the 1920s, and the accumulated experience of trade associations working with government agencies, the environment was conducive to more substantial changes in stateeconomy relations. 
Roosevelt and the Associational Regime

In 1932 there was little to suggest that the presidential election would result in consequential policy change. The Democratic platform was markedly conservative; the Roosevelt economic program was lacking coherence. Some of Roosevelt's statements alluded to a need for industrial planning, such as his claim that the nation needed an "enlightened administration" to engage in the "business of administering resources and plants already in hand . . . of adjusting production to consumption, of distributing wealth and products more equitably, of adapting existing economic organizations to the service of the people." While corporations would "work together to achieve the common end," the state would restrain "the lone wolf [who] declines to join in achieving an end recognized as being for the public welfare, and threatens to drag the industry back to a state of anarchy." 32 The state would engage in planning to manage production and distribution. ${ }^{33}$ Yet, as Rexford Tugwell cautioned, Roosevelt tended to move from the advocacy of planning to calls for antitrust enforcement because "he had a general indifference to systems of all sorts" and was busy "appealing first to one, then to another, group of voters." 34 With respect to the overall vision of a planned economy, Raymond Moley concluded, Roosevelt "did not adopt the alternative ideology, perhaps never quite understood it; he was, in fact, inconsistent." 35

In this context, administration policies reflected the interests of key advisers who were themselves divided along the lines drawn two decades earlier when the New Nationalism of Roosevelt confronted the New Freedom of Wilson. ${ }^{36}$ Despite the clear conflicts or perhaps because of them, Roosevelt reached into the usable past to resurrect the procedures and state-corporate relations developed during the war. The associationalism of the 1920s, myriad recovery plans, and the experiences of some of Roosevelt's advisers, themselves veterans of the wartime agencies, gave the model of the WIB great credibility. This was somewhat remarkable given the disparate economic tasks in question. During the war, policymakers had to boost production and fight inflation. In 1933 the goals were the opposite. The administration had to curb deflation and place restraints on competition and production. While Moley and Tugwell could provide a theroretical defense of planning, one suspects that the political expediency of a program that promised to forge a broad coalition of corporations and unions was far more important. ${ }^{37}$

The National Industrial Recovery Act created a system of governmentsupervised self-regulation by vesting power in corporations and their representative organizations and authorizing industrial groups to establish codes 
under an antitrust exemption. The process promoted agreements that maintained artificially high prices to fight deflation. Section 7(a) required each code to acknowledge labor's "right to organize and bargain collectively through representatives of their own choosing." It prohibited business interference with representation and required compliance with labor standards governing maximum hours, minimum wages, and other working conditions. Roosevelt presented the new system as one in which "all employers in each trade" will join "modern guilds-without exception-and agree to act together and at once." Roosevelt explained that the "old principles of unchecked competition" were to be superseded by "new Government controls." 38 In design and justification, the act was a direct expression of New Nationalism and an heir to the legacy of wartime planning.

Hugh Johnson, formerly an Army representative on the WIB, directed the NRA to use patriotic appeals borrowed wholesale from the war effort to reinforce the self-interest of participating corporations. In the end, the NRA approved 557 basic and 189 supplementary codes, bringing 95 percent of all industrial workers under the provisions of Section 7(a). Nevertheless, the codes were fraught with problems. Because the NRA lacked the necessary expertise, it delegated formidable authority to the code authorities without carefully evaluating the impact of industry agreements. The codes commonly favored the core firms that were overrepresented in the code authorities and were biased against smaller businesses, leading to conflicts among corporations in the same industry. As the economy showed signs of recovery, larger export-oriented, capital-intensive firms became anxious with the domestic focus of the NRA: large firms in the steel, automobile, and chemical industries discounted further participation. Finally, the Supreme Court delivered the coup de grace inn 1935, when it unanimously rejected the act on constitutional grounds. ${ }^{39}$

\section{Regulation After the NRA}

New Deal historians often separate the first and second New Deals. During the first New Deal, the administration worked intimately with business in the corporatist framework established by the NIRA. Following the Court decision invalidating the NIRA and the defection of business from the administration's programs, there was a shift in emphasis and a resurgence of the Wilsonian Progressivism. New programs extended the labor policy, revitalized antitrust, and set the foundations of a national welfare state. While a change in emphasis is clearly evident, an examination of regulatory policies initiated in the wake of the NRA reveals continued support for the organizing principles of the associational regime. In most 
cases, new initiatives integrated organized interests into the regulatory process and allowed them to exercise quasi-public authority as part of the system of government-supervised self-regulation.

Of course, many of the initiatives of the period appear, at least in design, to have far greater connections to the older Progressivism than to the events during the first New Deal. New policies regulated telephones, trucks and buses, and air transportation through the issuance of certificates of public convenience and necessity. This model of public utility regulation seems to have few connections to system of government supervised self-regulation until one examines the process whereby regulators determined rates and restricted entry of new concerns. Usually, these decisions were made in close consultation with established corporations and with a concern over the impact on the profitability of existing actors. Moreover, the regulatory process provided ample opportunities for established actors to challenge attempts to reduce rates or introduce greater competition, even though with the partial exception of communications, the structural preconditions for a natural monopoly were absent.

Agricultural regulation clearly displays the defining features of the associational regime. Following U.S. ข. Butler (1936), Congress and the administration moved quickly to retain the core features of the Agriculture Adjustment Act. The Soil Conservation and Domestic Allotment Act of 1936, the Agricultural Marketing Act of 1937, and the second Agricultural Adjustment Act of 1938 established the associationalist regulatory structure on firm foundations. The key features of the associational regime were quite evident in the agricultural regulatory system. First, Congress delegated authority to the USDA, a highly professionalized agency with close connections to the agriculture schools and the agricultural economics departments at major land-grant institutions and an ongoing circulation of personnel between government service and the universities. ${ }^{40}$ Second, regulators placed a premium on producer organizations to make and implement policies under USDA supervision. Where these organizations did not exist, the USDA created them and vested them with public authority. Finally, as with the NRA, the goal was not to preserve markets but to assure income stability and purchasing power well above that which would have existed under market conditions. However, the success of agricultural regulation came at a relatively high cost. The associationalist system undermined attempts to use agricultural policy to address rural poverty and created a strong bias supporting the largest farms which would come to claim the majority of subsidies. ${ }^{41}$

The case of industrial relations is equally suggestive. Following the 1935 passage of the Wagner Act, the National Labor Relations Board 
accelerated its efforts to organize workers and certify unions. By the end of 1939 , more than 25,000 cases had been filed with the NLRB and union membership almost doubled, increasing from some 3.75 million to more than 6.55 million. The organization of labor and the selection of representatives-both promoted and facilitated by the New Deal labor policies-allowed for a stable regulatory system that would promote collective bargaining absent the unstructured conflicts of the past. This was combined with equally significant developments within the NLRB. The board was professionalized around a core of attorneys representing the nation's best law schools. ${ }^{42}$ As Christopher Tomlins explains, this legal professionalization "ensured that from the outset its model in both organizational and procedural matters would be one rooted firmly in professional legal practice." 43 As a result, the parameters of industrial conflict were narrowly drawn: questions of workplace control and the constant threat of labor militancy were replaced by limited debates over wages, hours, and benefits supervised by regulators who were professionally inclined to observe norms of due process. The regulatory system introduced greater conservatism into the labor movement. This was precisely the point. The New Deal legacy in the industrial relations was similar to that in agriculture. The goal was to promote and supervise the organization of the regulated interests to achieve stability.

The posture in agriculture and labor was more or less consistent with that adopted in 1933. However, even the more difficult case of securities and exchange regulation reveals a strong element of associationalism. New Deal securities legislation was drafted by disciples of Louis Brandeis who opposed any scheme that entailed planning. Indeed, in design the regulatory system reflected the influence of Brandeis's earlier calls for regulation through disclosure. While legislation such as the Securities Act and the Securities and Exchange Act clearly carried the imprint of Wilsonian Progressivism, associationalism dominated implementation. In the case of the New York Stock Exchange, the Securities and Exchange Commission threatened direct regulation, thus forcing a reorganization of the exchange. A salaried, nonmember president, supported by an expert staff, replaced the cadre of Old Guard specialists and traders who had dominated the exchange. Under the direct supervision of the SEC, the exchange adopted a host of SEC-approved rules governing the behavior of its members, thus establishing a system of self-regulation. ${ }^{44}$

In the over-the-counter (OTC) market, the supervised self-regulation was even more apparent. An SEC commissioner compared regulating the OTC market to "trying to build a structure out of dry sand. There is no cohesive force to hold it together, no organization with which we can 
build, as authoritatively representing a substantial element in the overthe-counter business." 45 To remedy the situation, the SEC formally organized the sector. In 1938 it promoted an amendment to the Securities and Exchange Act that authorized the SEC to register national OTC associations charged with developing and enforcing rules "designed to prevent fraudulent and manipulative acts and practices, to promote just and equitable principles of trade, to provide safeguards against unreasonable profits . . . and, in general, to protect investors and the public interest." It designated the National Association of Securities Dealers as the sole regulatory organization for the OTC market. As Thomas McCraw notes, NASD "assumed the functions and structure of a regulatory agency. At the SEC's insistence, it began to develop its own professional staff which eventually included several hundred examiners and investigators." 46 It conducted investigations on its own initiative and at the request of the SEC and exercised the authority to expel those that violated NASD regulations. Thus, the SEC organized a highly decentralized industry and placed it under the supervision of a trade association vested with quasipublic authority.

\section{Regulating the Advanced Industrial Economy}

During the postwar period, the associational regime's system of government-supervised self-regulation and the emphasis placed on industrial stability created great benefits for the regulated. This stability, however, appeared to many to be little more than regulatory capture-the sacrifice of the public welfare for corporate profits. Proponents of the new social regulations demanded an extension of public policies to a host of so-called quality-of-life issues, including environmental protection, occupational health, and consumer product safety. Moreover, they demanded new institutions that could resist the influence of the regulated while providing a new and expansive role for citizen groups previously excluded from the regulatory process in existing agencies.

Because social regulatory policies are classic examples of policies with concentrated costs and diffuse benefits, enabling legislation can be extremely difficult to pass. Initially, political entrepreneurs in the Senate, attracted by the populist focus of the new social regulations, exploited salient events and exposés to secure the passage of early social regulatory legislation. ${ }^{47}$ However, new consumer and environmental groups quickly created a natural constituency for social regulation. The number of advocacy groups increased dramatically during the late 1960s and 1970s. Fully 
76 percent of the public-interest groups active in the 1980 s were founded during this period. ${ }^{48}$ Several factors, including the modern muckraking of Ralph Nader and the experiences of the civil rights and antiwar movements, explain the proliferation of groups. However, as Harris and Milkis correctly suggest, the New Left was critical in shaping the political environment. It invested political activities with theoretical significance and provided a useful reference point for many participants. ${ }^{49}$

The New Left's vision of society as managed by large corporate, military, and governmental bureaucracies required the repudiation of hierarchy and an affirmation of participatory democracy. Herbert Marcuse declared: "The new radicalism militates against the centralized bureaucratic communist as well as against the semi-democratic liberal organization. . . . The initiative shifts to small groups, widely diffused, with a high degree of autonomy, mobility, flexibility." 50 The New Left critique called for the creation of grassroots organizations to combat the power of the corporate state. A growing number of these groups focused on quality-of-life concerns. It was argued that a capitalist system organized in pursuit of high profit margins via mass production and marketing destroyed the environment, sacrificed workers, and exploited consumers. Regulatory policies could address the excesses of advanced industrial production. Such policies, however, would be successful if and only if policymakers combined them with efforts to democratize the regulatory state.

Many argued that administrative failure resulted in policies that enhanced corporate profits rather than consumer welfare. Thus, policy demands were linked to a critique of existing institutions and administrative practices. Works such as Bernstein's Regulating Business by Independent Commission and Kolko's The Triumph of Conservatism suggested that regulatory agencies were either created to serve the needs of large corporations or quickly passed through an administrative life cycle to reach a point where regulators saw the regulated interests as the only available constituency. ${ }^{51}$ The institutional critique went beyond the question of organizational form to address the chief failures of the policy process. Theodore Lowi and Kenneth Culp Davis, in particular, focused on the lack of democratic control and accountability that flowed from the excessive delegation of authority. ${ }^{52}$ When Congress delegated authority without clear statutory standards, administrators defined policy through reference to the demands of powerful interests that dominated the implementation process. Because Congress initiated policy without providing a clear statutory plan, there was little legislative guidance of implementation. Delegation depreciated that which was central to any democratic system. The most powerful interests claimed a key role in defining policy at the agency 
level, thus substituting power and privilege for the democratic norms adhered to within the legislative process.

The Limits of Institutional Engineering

The regulatory initiatives of the 1970 s evinced the assessments of prevailing institutional designs. When Congress and the President created new regulatory agencies, they selected forms other than the independent commission (e.g., OSHA in the Labor Department, the EPA as an independent agency). Congress gave the Consumer Product Safety Commission (the one significant exception to this generalization) a commission form to thwart President Nixon's attempts to place the new agency in the Department of Health, Education, and Welfare, a move that could make the agency vulnerable to business influence. ${ }^{53}$ Beyond organization, there was a concern over vague legislation and the delegation of authority it entailed. Thus, the new initiatives departed from earlier acts with respect to their specificity and extent of delegation. Legislation addressing air and water pollution forced the EPA to abide by relatively precise implementation timetables. Thus, under the provisions of the Clean Air Act of 1970, Congress directed the EPA to establish primary and secondary National Ambient Air Quality Standards for pollutants that threatened the public health or welfare within 30 days, and issue final standards within 120 days. The same legislation required that automakers reduce carbon monoxide and hydrocarbons by 90 percent by 1975 , with parallel decreases in nitrogen oxide emissions by 1976 . While the goals and timetables may have been unrealistic, they limited agency discretion and fostered an adversarial relationship with the regulated. The stringent timetables of the new social regulations created significant problems, especially at the EPA, where the deadlines left little opportunity for careful consideration of the scientific evidence and the underlying assumptions. Moreover, EPA regulators recognized that the standards were difficult to justify with scientific evidence and often were simply unachievable. ${ }^{54}$ Because the targets for pollution reduction were too ambitious, failed implementation and successive legislative extensions became inevitable.

A second distinguishing feature was the role of interest groups. Congress designed the regulatory initiatives to give advocacy groups a far greater part in the policy process than would have been possible in earlier regulatory regimes. The rulemaking processes in agencies such as EPA and OSHA were exceedingly complex, with multiple layers of review and opportunities for group input. ${ }^{55}$ In addition, legislation like the Clear Air Act granted citizens standing to sue the agency for a failure to fulfill its 
mandate. Advocacy groups could appeal to the courts to force compliance with the regulatory initiatives - an opportunity they use frequently. Some of the regulatory legislation authorized intervener funding programs designed to provide interest groups the financial resources to participate in agency decisionmaking. The goal of all of these provisions was to democratize the regulatory system and guarantee groups a continuous presence in implementation.

The participatory elements of the societal regime created distinct problems. Extended rulemaking and high levels of participation retarded the standard-setting process. Once promulgated, standards inevitably faced legal challenges. The high probability of litigation introduced greater conservatism into the policy process, forcing agencies such as OSHA and EPA to consider legal issues at an early stage, often to the detriment of the underlying scientific foundations and legislatively established goals. ${ }^{56}$ Nevertheless, as Melnick's study of the Clean Air Act reveals, the interest-group challenges and judicial decisions introduced greater incoherence into environmental policy. The courts forced the EPA to devote resources to new enforcement efforts (e.g., preventing serious deterioration of regions in compliance with standards) regardless of the effects on primary policy goals. Likewise, judicial decisionmaking rested on limited knowledge of the underlying scientific research and methodological assumptions. The decentralization of the judiciary resulted in the appeal to different scientific assumptions and readings of the regulatory legislation and lower court decisions that were often difficult to reconcile. ${ }^{57}$

Although critics cast a dark shadow over delegation and its effects on democratic accountability, legislators did not eschew delegation, even if heightened legislative specificity created an appearance to the contrary. The tasks executed by regulators (e.g., determining chemical toxicity and acceptable levels of risk) were far more complex than those addressed by their economic counterparts. The new regulatory mandates required agencies to place a premium on scientific research. Legislation could require the EPA to develop national ambient air quality standards within a specific time frame and force predetermined reductions in pollution levels by a specific date. However, there was no way to dictate which scientific assumptions and data would be used in this endeavor. The complexity of the new regulatory problems and the unprecedented dependence on expert analysis made policy highly vulnerable to the quality of the scientific assumptions and research employed in the policy process. It should be no surprise that the adequacy of the underlying analyses and data became the growing focus of regulatory politics in the 1970s and 1980s. 
Under the market and associational regimes, experts played an important part in the definition and implementation of policy. The role assigned to experts in the societal regime was historically unprecedented. This delegation of authority was, in many ways, more problematic than earlier acts of delegation. Social scientific and scientific professionals claim their authority on the basis of the highly specialized knowledge and skills they have mastered through intensive postgraduate education. The highly specialized language and methodologies employed by the appropriate professional groupings allow for communication and participation in a common set of research programs. It also excludes those lacking the necessary training from the pertinent debates. This creates an immense barrier for those who would attempt to oversee the activities of scientific and social scientific professionals. ${ }^{58}$ While legislation could provide ample opportunities for group participation, it could not provide interested parties with the expertise necessary to make significant contributions or to expose the regulators to anything resembling efficacious oversight. Groups capable of employing their own professional staffs or consultants possessed an advantage in rulemaking and subsequent attempts to shape implementation. Indeed, this is the most ironic aspect of the societal regime. Many groups that proved influential in shaping the regulatory agenda discovered that the resource demands associated with active participation were simply prohibitive.

\section{Deregulation, Reform, and Industrial Decline}

As noted throughout, a regulatory regime consists of a linked set of policies and institutions. The shared reference point, dominant politicaleconomic coalitions, and a common set of political-economic theories and administrative reform doctrines produce a certain consistency across regulatory arenas. The regulatory regimes discussed above had democratic roots: citizens and social groups demanded an adjustment in the pattern of state-economy relations to preserve or promote particular values and interests. The regulatory reform and deregulation of the past two decades forced changes in policies and institutions of a magnitude equal to those in earlier periods and marked the emergence of a new regime. Poor macroeconomic performance was the dominant issue during the presidencies of Nixon, Ford, Carter, and Reagan. In 1973 the combination of increases in food prices and an OPEC oil embargo had a dramatic impact on the inflation rate, which was combined with low levels of growth and persistent unemployment- the second component of economic stagfla- 
tion. The problem of economic stagflation revealed the weakness of existing macroeconomic policy tools and accelerated the disintegration of the Keynesian consensus. As economic performance became increasingly salient, policymakers had to provide a policy response. Although there was little evidence to link regulation and the economic maladies of the day, deregulation and regulatory reform became politically attractive. Officials could present them as components of a comprehensive attack on stagflation. Moreover, they could meet the demands of corporate actors who had secured a new political presence due to the heightened levels of corporate organization and mobilization and changes in the campaign finance laws. ${ }^{59}$

This concern with corporate performance and profitability found an expression in a series of institutional changes premised on the belief that justifiable regulations must yield net social benefits. During the 1970 s presidents initiated and expanded regulatory review processes centralized in the Executive Office of the President. The executive review processes began in earnest with President Ford's Executive Order 11,821, requiring that agencies accompany major regulations and rules with an inflationary impact statement. The order assigned responsibility for reviewing the statements to the Council on Wage and Price Stability and the OMB. The Carter administration continued these activities with an expansion of the impact-statement program and the creation of the Regulatory Analysis Review Group and the Regulatory Council in 1978. The evolution of regulatory review culminated in the Reagan administration, when Executive Order 12,291 required executive agencies to provide a costbenefit justification for major rules and regulations. The OMB's Office of Information and Regulatory Affairs analyzed these justifications and had to approve all regulations before publication in the Federal Register. ${ }^{60}$

The review process raised distinct concerns, particularly during the Reagan administration. The economic analysis required for executive review forced agencies to integrate new decision rules into the policy process. Agencies had to justify new and existing policies through a comparison of their costs and benefits. When Congress wrote key pieces of social regulatory legislation, it commonly discounted cost considerations and emphasized the importance of public health or environmental preservation. The imposition of economic analysis appeared to many to entail a subversion of politically defined goals. Second, the executive review processes provided various business associations with an additional point of access, an opportunity to contest administrative decisions that they found unduly intrusive or costly. Opponents charged that these communications fell outside the safeguards of the Administrative Procedure Act. ${ }^{61}$ 
The poor performance of the 1970 s also stimulated progressive waves of deregulation. Although the economic regulatory agencies weathered the major deregulatory initiatives, there were efforts to introduce market-based innovations in the social regulatory agencies (e.g., bubbles and emissions trading at the EPA). During the 1970s and early 1980s, Congress passed legislation deregulating surface transportation, air transportation, financial institutions, and energy. This legislation commonly followed deregulatory initiatives in the agencies. Throughout the 1970s, virtually all regulatory agencies underwent professionalization. Agencies that had long functioned as large litigation shops created economics staffs and policy planning and evaluation offices. In many cases, this economic professionalization was a response to the analytical demands of executive review processes. Agencies sought to internalize the debates over costs and benefits to limit their vulnerability to executive challenges. Economics staffs increasingly brought their disciplinary paradigms to bear in evaluating policy. The concern over the potential inflationary impact of regulation led economists and policy planning staffs to consider deregulatory activities at the agency level. ${ }^{62}$

The introduction of new (corporate)) interests, ideas (economic analysis), and institutions (executive review centralized in the $\mathrm{OMB}$ ) suggest the emergence of a new regulatory regime. One can characterize the new regime by its key features. First, there was an unprecedented centralization of regulatory authority in the OMB and White House review bodies. Second, economic analysis provided the primary guide to determining the justification for regulations. Third and related, the market became a benchmark in assessing the need for policy and designing new policies, reflecting the faith in market mechanisms and the self-regulatory capacities of corporations. Fourth, the regulatory reform and deregulation efforts were driven by an overwhelming concern with corporate compliance costs; social benefits were weighed against the costs incurred by corporations. Given the central role of efficiency in the new politics of regulation, it is appropriate to refer to this regime as the efficiency regime.

The characteristics of the efficiency regime clearly distinguish it from earlier regimes. Unlike the market regime, which sought to revitalize or replicate decentralized markets, the new regime recognizes few sources of market failure. The new regime shares with the New Deal's associational regime a faith in the self-regulatory capacities of economic actors. However, it de-emphasizes the need for active government supervision because market forces, it is believed, will eliminate inefficient corporate practices and modes of organization. Finally, the new regime departs from the societal regime of the 1960 s and 1970 s in the core assumption that corpo- 
rate compliance costs must be considered when determining the justification for many of the new regulatory policies. Environmental protection and worker safety are considered to be of secondary importance to corporate profitability and economic competitiveness.

Unlike the three regulatory regimes examined above, the emerging regime was not the product of popular politics. To be certain, many of public-interest groups, drawing on reports on the mismanagement of several well-established regulatory agencies, constituted a natural constituency for deregulation. However, public opinion polls conducted during the period reveal strong and growing support for regulation. ${ }^{63}$ While it may be tempting to dismiss the emergence of a new regime due to the lack of popular origins, ${ }^{64}$ there is reason to believe that the changes of the period may be indicative of a new regulatory politics, one that has sources internal to the regulatory agencies and the highly specialized policy communities that surround most policy arenas. The growing complexity of regulatory policy and the heightened role of expertise suggest that regulatory change may increasingly reflect factors other than popular politics. As the discourse surrounding a given policy area becomes increasingly complicated, the universe of actors capable of contributing to the policy debates and actively engaging in regulatory politics becomes highly restricted. Workers may believe that workplace exposure to toxic chemicals is unacceptable; they may promote policies that extend regulations over the production process. However, the complexity of risk assessment and the scientific foundations of occupational health policy may prove to be insurmountable barriers to effective participation. Likewise, as the acceptability of a given policy comes to depend on the results of highly specialized economic analyses conducted within the OMB and agency policy offices, the political justifications for policy may assume a secondary status. Advocacy groups may enter into the highly specialized debates by maintaining research staffs and conducting their own analyses. The resources demanded by such an enterprise will once again limit the universe of interests capable of engaging in regulatory politics.

In this article I have applied a regime framework to explore the factors shaping the major waves of regulatory change in this century. The market, associational, societal, and efficiency regimes consisted of different configurations of institutions and policies, roles for organized interests, and goals, resulting in different patterns of state-economy relations. As I have argued throughout, unique features of the four regimes can be tied to their origins, the interests mobilized, and the political-economic and administrative reform doctrines that shaped the initiatives. A regime framework provides 
a useful tool for making sense of regulatory history. It focuses attention on continuity and change across policies and institutions.

The regime framework, however, remains in need of further refinement. The ideas and interests identified by the framework as being critical in shaping a new regime are suggestive but nonetheless indeterminate. In the language of social science, regulatory regimes are intervening variables connecting economic-structural change and changes in stateeconomy relations. By identifying the key features of regulatory regimes, one can enhance one's understanding of the origins of a given set of policy and institutional reform initiatives. Yet it is difficult to exclude competing explanations of regulatory change. One can effectively explore the relationships between interests, ideas, and regulatory change but remain incapable of generating unique predictions. Perhaps this is not of critical importance. Historically-based research does not strive to generate theories that are fully determinate. Perhaps we can be content with explanation and interpretation. The potential for greater theoretical precision exists and needs to be explored. This will come only as a product of more detailed case studies of regulatory change and a closer interplay between empirical research and theory construction.

Moreover, a critic might charge that the focus on regulatory policy is artificial, reflecting contemporary divisions in the subfields of policy studies. Connections between regulatory policies and other policies are evident in each period and demand exploration. For example, consider the connections between regulation and other economic and social policies. Democratic tariff reductions during the Wilson administration, designed in part to limit monopoly power and allow competitive forces to promote corporate efficiency, accompanied the Progressive market regime in regulation. Likewise, one can identify clear connections between the associational regime's focus on stability and a politically determined distribution of national income, the Social Security Act of 1935, and the debates over full employment legislation in 1946 and 1947. Of course, in the contemporary period, the support for supply-side economics, welfare reform, and market-based innovations in education, public housing, and urban renewal closely parallels the changes in regulatory politics. Rather than defining the substantive parameters of regimes to correspond with subfields in policy studies, it may be useful to extend the regime framework to the examination of other policy areas, thereby constructing a more comprehensive account of policy origination and administrative change. 


\section{Notes}

1. Donald J. Puchala and Raymond F. Hopkins, "International Regimes: Lessons from Inductive Analysis," in International Regimes, ed. Stephen D. Krasner (Ithaca, N.Y., 1983), 61-62. Regulatory regimes are addressed in great detail in Richard A. Harris and Sidney M. Milkis, The Politics of Regulatory Change: A Tale of Two Agencies (New York, 1989).

2. See the more extensive case studies of regulatory policies and regimes in Marc Allen Eisner, Regulatory Politics in Transition (Baltimore, 1993).

3. See, for example, the discussion of regional economic cleavages in Elizabeth Sanders, "The Regulatory Surge of the 1970s in Historical Perspective," in Public Regulation: New Perspectives on Institutions and Policies, ed. E. E. Bailey (Cambridge, Mass., 1987). See the discussion of the role of ideas in coalition formation in Paul A. Sabatier, "An Advocacy Coalition Framework of Policy Change and the Role of Policy-Oriented Learning Therein," Policy Sciences 21 (1988): 129-68. See also John Kingdon, Agendas, Alternatives, and Public Policies (Boston, 1984).

4. Margaret Weir and Theda Skocpol, "State Structures and the Possibilities for 'Keynesian' Responses to the Great Depression in Sweden, Britain, and the United States," in Bringing the State Back In, ed. P. B. Evans, D. Rueschemeyer, and T. Skocpol (Cambridge, 1985).

5. See Robert Higgs, Crisis and Leviathan: Critical Episodes in the Growth of American Government (New York, 1987), 79-80; Alfred D. Chandler Jr., "United States: Seedbed of Managerial Capitalism," in Managerial Hierarchies: Comparative Perspectives on the Rise of the Modern Industrial Enterprise, ed. A. D. Chandler, Jr., and H. Daems (Cambridge, Mass., 1980); Thomas K. McCraw, "Mercantilism and the Market: Antecedents of American Industrial Policy," in The Politics of Industrial Policy, ed. C. E. Barfield and W. A. Schambra (Washington, D.C., 1986), 32; and Lewis L. Gould, "The Progressive Era," in The Progressive Era, ed. L. L. Gould (Syracuse, N.Y., 1974), 2.

6. See Louis Galambos, "The Emerging Organizational Synthesis in Modern American History," Business History Review 44,3 (1970): 279-89; Robert H. Weibe, The Search for Order, 1877-1920 (New York, 1967); Samuel P. Hays, The Response to Industrialism, 18851914 (Chicago, 1957), 54-57; and Thomas McCraw, "Rethinking the Trust Question," in Regulation in Perspective, ed. Thomas K. McCraw (Cambridge, Mass., 1981).

7. Foster Rhea Dulles and Melvyn Dubofsky, Labor in American History, 4th ed. Arlington Heights, Ill., 1984), 121-41, 196.

8. See Solon Buck, The Granger Movement (Cambridge, Mass., 1913), and John D. Hicks, The Populist Revolt (Lincoln, Neb., 1961).

9. See David B. Danbom, The World of Hope: Progressives and the Struggle for an Ethical Public Life (Philadelphia, 1987).

10. Stephen Skowronek, Building a New American State: The Expansion of National Administrative Capacities, 1877-1920 (Cambridge, 1982), 168-69.

11. Higgs, Crisis and Leviathan, 115.

12. Richard T. Ely, Ground Under Our Feet (New York, 1938), 135.

13. Louis D. Brandeis, Business-A Profession (Boston, 1914), 260.

14. Theodore Roosevelt, "The Big Stick and the Square Deal," in The Progressives, ed. C. Resek (Indianapolis, 1967), 190, and Theodore Roosevelt, The New Nationalism (Englewood Cliffs, N.J., 1961), 24.

15. Woodrow Wilson, The New Freedom: A Call for the Emancipation of the Generous Energies of a People (New York, 1913), 197, 202. See the discussion of the debates involving Wilson, Roosevelt, and Taft, in Martin J. Sklar, The Corporate Reconstruction of American Capitalism, 1890-1916 (Cambridge, 1988).

16. Marc Allen Eisner, Antitrust and the Triumph of Economics: Institutions, Expertise, and Policy Change (Chapel Hill, 1991), 50-51. 
17. See Frank J. Goodnow, Politics and Administration (New York, 1900), and Woodrow Wilson, "The Study of Administration," in The Administrative Process and Democratic Theory, ed. L. C. Gawthrop (New York, 1970). On the relationship between corporations and government agencies, see William $\mathrm{H}$. Becker, The Dynamics of Business-Government Relations: Industry and Exports, 1893-1921 (Chicago, 1982), 182-83, and David Vogel, "Why Businessmen Distrust Their State: The Political Consciousness of American Corporate Executives," British Journal of Political Science 8 (1984): 45-78.

18. Interstate Commerce Commission, Eleventh Annual Report of the Interstate Commerce Commission, December 6, 1897 (Washington, D.C., 1897), 51.

19. Eisner, Antitrust and the Triumph of Economics, 64-67.

20. Federal Trade Commission, Annual Report of the Federal Trade Commission (Washington, D.C., 1918), 22-25.

21. Robert E. Cushman, The Independent Regulatory Commissions (New York, 1941), 214-15; Thomas C. Blaisdell, The Federal Trade Commission: An Experiment in the Control of Business (New York, 1932), 86-87.

22. Correspondence of President Woodrow Wilson to Bernard M. Baruch, 4 March 1918, reproduced in Bernard M. Baruch, American Industry in the War: A Report of the War Industries Board (March 1921) (New York, 1941), 24-25.

23. John Maurice Clark, The Costs of War to the American People (New Haven, 1931), 34. Robert D. Cuff, The War Industries Board: Business-Government Relations During World War I (Baltimore, 1973), 158-76.

24. Cuff, The War Industries Board, 174.

25. Ellis W. Hawley, The Great War and the Search for a Modern Order (New York, 1979), 19.

26. Herbert Hoover quoted in Edwin T. Layton Jr., The Revolt of the Engineers: Social Responsibility and the American Engineering Profession (Baltimore, 1971), 190-91.

27. See Ellis W. Hawley, "Three Facets of Hoover Associationalism: Lumber, Aviation, and Movies, 1921-1930," in Regulation in Perspective: Historical Essays, ed. Thomas K. McCraw (Cambridge, Mass., 1981), and David F. Noble, America by Design: Science, Technology, and the Rise of Corporate Capitalism (New York, 1977), 76-83. For an analysis of the trade association movement and its relationship to the New Deal, see Robert F. Himmelberg, The Origins of the National Recovery Administration: Business, Government, and the Trade Association Issue, 1921-1933 (New York, 1976).

28. William J. Barber, From New Era to New Deal: Herbert Hoover, the Economists, and American Economic Policy, 1921-1933 (Cambridge, 1985), 104-45, and William E. Leuchtenburg, "The New Deal and the Analogue of War," in Change and Continuity in Twentieth-Century America, ed. John Braeman, Robert H. Bremner, and Everett Walker (Columbus, Ohio, 1965), 99.

29. Thomas Ferguson, "Industrial Conflict and the Coming of the New Deal: The Triumph of Multinational Liberalism in America," in The Rise and Fall of the New Deal Order, 1930-1980, ed. Steve Fraser and Gary Gerstle (Princeton, 1989).

30. Robert M. Collins, The Business Response to Keynes, 1929-1964 (New York, 1981), 23-28.; and Barber, From New Era to New Deal, 121-22; Hawley, The Great War and the Search for a Modern Order, 201; Leuchtenburg, "The New Deal and the Analogue of War," 94-95.

31. Kim McQuaid, Big Business and Presidential Power: From FDR to Reagan (New York, 1982), 24.

32. Franklin D. Roosevelt, "Everyman Has a Right to Live," campaign speech delivered 23 September 1932, reprinted in New Deal Thought, ed. Howard Zinn (Indianapolis, 1966), 49-50, 52.

33. Franklin D. Roosevelt, "Bold, Persistent Experimentation," campaign Speech delivered 22 May 1932, reprinted in New Deal Thought, 81.

34. Rexford G. Tugwell, In Search of Roosevelt (Cambridge, Mass., 1972), 116-17. 
35. Raymond Moley, After Seven Years (New York, 1939), 189-90.

36. See Donald R. Brand, Corporatism and the Rule of Law: A Study of the National Recovery Administration (Ithaca, N.Y., 1988), for a discussion of the NRA as a corporatist experiment. The account of the divisions in the Roosevelt administration should be compared with the argument made in Ellis W. Hawley, The New Deal and the Problem of Monopoly: A Study in Economic Ambivalence (Princeton, 1966).

37. Lechtenburg, "The New Deal and the Analogue of War," 117, 129.

38. Statement by the President of the United States of America Outlining Policies of the National Recovery Administration, June 16, 1933." Reprinted in Hugh S. Johnson, The Blue Eagle from Egg to Earth (New York, 1935), 440, 441.

39. Otis L. Graham, Jr., Toward a Planned Economy: From Roosevelt to Nixon (New York, 1976), 30; Anthony J. Badger, The New Deal: The Depression Years, 1933-1940 (New York, 1989), 88-92; Gerald Swope, "Planning and Economic Organization," The Proceedings of the Academy of Political Science 15, 4 (January 1934): 452-57; and William E. Leuchtenburg, Franklin D. Roosevelt and the New Deal: 1932-1940 (New York, 1963), 84-90.

40. Kenneth J. Meier, Regulation: Politics, Bureaucracy, and Economics (New York, 1985), 123-26. For an extended discussion of the policy area during the New Deal, see Theda Skocpol and Kenneth Finegold, "State Capacity and Economic Intervention in the Early New Deal," Political Science Quarterly 97,2 (1982): 255-78.

41. See Richard S. Kirkendall, "The New Deal and Agriculture," in The New Deal: The National Level, ed. J. Braeman, R. H. Bremner, and D. Brody (Columbus, Ohio, 1975). For a discussion of the effects of agricultural policy on the structure of the sector, see Charles L. Schultze, The Distribution of Farm Subsidies: Who Gets the Benefits? (Washington, D.C., 1971), 29.

42. Christopher L. Tomlins, The State and the Unions: Labor Relations, Law, and the Organized Labor Movement in America, 1880-1960 (Cambridge, 1985), 148-56; Dulles and Dubofsky, Labor in American History, 288. Peter H. Irons, The New Deal Lawyers (Princeton, 1982), 236.

43. Tomlins, The State and the Unions, 154.

44. Michael E. Parrish, Securities Regulation and the New Deal (New Haven, 1970), 21416; Joel Seligman, The Transformation of Wall Street: A History of the Securities and Exchange Commission and Modern Corporate Finance (Boston, 1982), 164-86.

45. Quoted in Parrish, Securities Regulation and the New Deal, 214.

46. Thomas K. McCraw, "With Consent of the Governed: SEC's Formative Years," Journal of Policy Analysis and Management 1 (1982): 359.

47. James Q. Wilson, Political Organizations (New York, 1973); David Vogel, Fluctuating

Fortunes: The Political Power of Business in America (New York, 1989), 38-42.

48. Kay Schlozman and John T. Tierney, Organized Interests and American Democracy (New York, 1986), 76.

49. See Harris and Milkis, The Politics of Regulatory Change, and Jeffrey M. Berry, The Interest Group Society (Boston, 1984), 16-45.

50. Herbert Marcuse, An Essay on Liberation (Boston, 1969), 89. Other representative works include G. William Domhoff, Who Rules America? (Englewood Cliffs, N.J., 1967), and Charles A. Reich, The Greening of America (New York, 1970).

51. See Marver H. Bernstein, Regulating Business by Independent Commission (Princeton, 1955); Gabriel Kolko, The Triumph of Conservatism: A Reinterpretation of American History, 1900-1916 (New York, 1963), Grant McConnell, Private Power and American Democracy (New York, 1966).

52. See Theodore Lowi, The End of Liberalism (New York, 1969), and Kenneth Culp Davis, Discretionary Justice: A Preliminary Inquiry (Baton Rouge, La., 1969). For a discussion of the effects of the critique on the courts, see Richard B. Stewart, "The Reformation of American Administrative Law," Harvard Law Review 88 (1975): 16671813. 
53. Terry M. Moe, "The Politics of Bureaucratic Structure," in Can the Government Govern? ed. J. E. Chubb and P. E. Peterson (Washington, D.C., 1989).

54. For a discussion of the conflicts between the new mandates and administrative factors, see Alfred A. Marcus, Promise and Performance: Choosing and Implementing an Environmental Policy (Westport, Conn., 1980).

55. For a survey of the rulemaking process in a number of social regulatory agencies, see Gary C. Bryner, Bureaucratic Discretion: Law and Policy in Federal Regulatory Agencies (New York, 1987).

56. See Graham K. Wilson, The Politics of Safety and Health: Occupational Safety and Health in the United States and Great Britain (Oxford, 1985), 64.

57. R. Shep Melnick, Regulation and the Courts: The Case of the Clean Air Act (Washington, D.C., 1983). Also see Lettie McSpadden Wenner, "The Courts and Environmental Policy," in Environmental Politics and Policy: Theories and Evidence, ed. J. P. Lester (Durham, N.C., 1989).

58. Douglas Yates, Bureaucratic Democracy: The Search for Democracy and Efficiency in American Government (Cambridge, Mass., 1982), 121-48; and Eisner, Antitrust and the Triumph of Economics, 90-118.

59. For a discussion of the resurgence of business groups in the $1970 \mathrm{~s}$ and 1980 s, see Vogel, Fluctuating Fortunes, and Thomas Byrne Edsall, The New Politics of Inequality (New York, 1984).

60. See Thomas O. McGarity, Reinventing Rationality: The Role of Regulatory Analysis in the Federal Bureaucracy (Cambridge, 1991).

61. See Howard Ball, Controlling Regulatory Sprawl: Presidential Strategies from Nixon to Reagan (Westport, Conn., 1984).

62. See the discussion of the organizational foundations of deregulation in Martha Derthick and Paul J. Quirk, The Politics of Deregulation (Washington, D.C., 1985), and Marc Allen Eisner and Kenneth J. Meier, "Presidential Control Versus Bureaucratic Power: Explaining the Reagan Revolution in Antitrust," American Journal of Political Science 34, 1 (1990): 269-87. On the EPA, see Alfred A. Marcus, "Environmental Protection Agency," in The Politics of Regulation, ed. James. Q. Wilson (New York, 1980).

63. See Robert Y. Shapiro and John M. Gillroy, "The Polls: Regulation-Part I and II," Public Opinion Quarterly 48 (1984): 531-42, 666-77, and Thomas Ferguson and Joel Rogers, Right Turn: The Decline of the Democrats and the Future of American Politics (New York, 1986).

64. Harris and Milkis, The Politics of Regulatory Change, 293. 